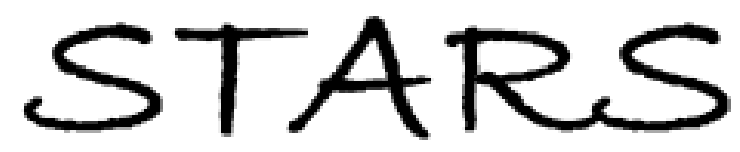

University of Central Florida

STARS

Faculty Bibliography 2000s

Faculty Bibliography

$1-1-2006$

\title{
E-commerce and Caulerpa: unregulated dispersal of invasive species
}

\author{
Linda J. Walters \\ University of Central Florida \\ Katherine R. Brown \\ University of Central Florida \\ Wytze T. Stam
}

Jeanine L. Olsen

Find similar works at: https://stars.library.ucf.edu/facultybib2000

University of Central Florida Libraries http://library.ucf.edu

This Article is brought to you for free and open access by the Faculty Bibliography at STARS. It has been accepted for inclusion in Faculty Bibliography 2000 s by an authorized administrator of STARS. For more information, please contactSTARS@ucf.edu.

\section{Recommended Citation}

Walters, Linda J.; Brown, Katherine R.; Stam, Wytze T.; and Olsen, Jeanine L., "E-commerce and Caulerpa: unregulated dispersal of invasive species" (2006). Faculty Bibliography 2000s. 4696.

https://stars.library.ucf.edu/facultybib2000/4696

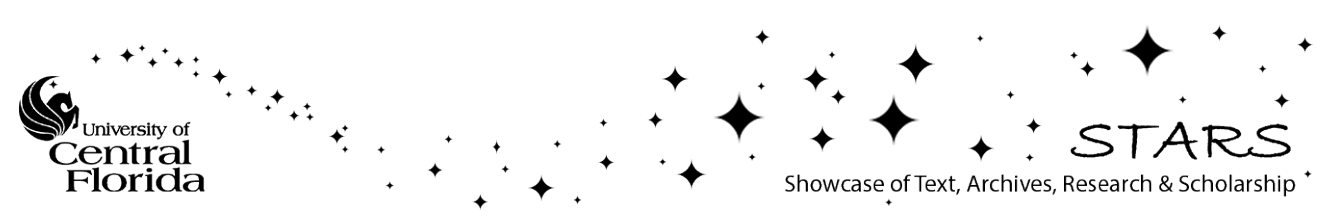




\title{
E-commerce and Caulerpa: unregulated dispersal of invasive species
}

\author{
Linda J Walters ${ }^{1 *}$, Katherine R Brown ${ }^{1}$, Wytze T Stam ${ }^{2}$, and Jeanine L Olsen ${ }^{2}$
}

Professional aquarists and hobbyists are thought to be the source of invasions of the aquarium strain of the green macroalga Caulerpa taxifolia in the Mediterranean, southern California, and Australia. The US Department of Agriculture, Animal and Plant Health Inspection Service (USDA-APHIS) restricted interstate commerce and importation of the Mediterranean clone of $C$ taxifolia prior to the California invasion and is currently deciding if it should strengthen regulation of this genus as more species of Caulerpa are being described as invasive. Here we document the importance of e-commerce as a mode of dispersal for many species of Caulerpa in the United States. We purchased Caulerpa from 30 internet retailers and 60 internet auction sites representing 25 states and Great Britain. Twelve different Caulerpa species were confirmed using DNA sequencing. Only $10.6 \%$ of sellers provided the correct genus and species names with their shipments. Thirty purchases of "live rock" provided four species of Caulerpa, as well as 53 additional marine species. Our results confirm the extensive e-commerce availability of this invasive genus and its high dispersal potential via postal services and hobbyists. We recommend that both eBay and the USDA maximize regulation of Caulerpa.

Front Ecol Environ 2006; 4(2): 75-79

$\mathbf{M}$ any species of the green macroalga Caulerpa (Chlorophyta: Ulvophyceae) are highly invasive and the economics and ecological impacts associated with these introductions are well documented (eg de Villèle and Verlaque 1995; Davis et al. 1997; Meinesz 1999; Williams and Grosholz 2002a). For example, monocultures of the aquarium strain of Caulerpa taxifolia extend hundreds of kilometers along the Mediterranean coastline (Meinesz et al. 2001), have clogged nine waterways in New South Wales and two more in South Australia (Schaffelke et al. 2002; Millar 2004; A Davis pers comm), and infested two lagoons in southern California (Jousson et al. 2000). In all cases, this invasive strain of $C$ taxifolia grew faster, larger, and in deeper and colder waters than its native tropical counterpart (Belsher and Meinesz 1995; Williams and Grosholz 2002b). DNA studies confirmed that the aquarium strain of $\mathrm{C}$ taxifolia originated near Brisbane, Australia, and was subsequently transported via the aquarium trade (Jousson et al. 1998; Wiedenmann et al. 2001; Muesnier et al. 2002). In the Mediterranean and the Canary Islands, Caulerpa racemosa is now also recognized as invasive (Verlaque et al. 2003, 2004). Similarly, non-native Caulerpa brachypus was first recognized in southeastern Florida waters in 2001, where extensive blooms were overgrowing or displacing native flora and fauna (Jacoby et al. 2004).

Despite its invasive reputation, many members of the genus Caulerpa (especially C racemosa, C prolifera, and

${ }^{1}$ Department of Biology, University of Central Florida, Orlando, FL 32816 USA *(ljwalter@pegasus.cc.ucf.edu); ${ }^{2}$ Department of Marine Biology, Center for Ecological and Evolutionary Studies, University of Groningen, The Netherlands

some of the "feather Caulerpas": C taxifolia, C sertularioides, and $\mathrm{C}$ mexicana) remain extremely popular with aquarium hobbyists because they are attractive in salt water tanks and are easy to clonally propagate (Smith and Walters 1999; Padilla and Williams 2004). The genus Caulerpa is also touted by hobbyists for its many additional virtues, most notably its ability to remove nutrients from closed aquarium systems and to act as fish food. However, as their aquaria become overgrown or situations change, hobbyists may either sell their extra stock on eBay or dispose of their unwanted algae (and animals) in nearby waters, thus setting the stage for a new invasion (Whitfield et al. 2002; Semmens et al. 2004).

"Live rock" is extremely popular with aquarists because it is inexpensive, and can potentially harbor a huge diversity of marine organisms (including Caulerpa spp). Many consider it to be an essential component of saltwater aquariums, as it acts as a substrate for sessile species, a refuge for fishes and mobile invertebrates, and as a biological filtration system. Live rock consists of either pieces of hard coral directly harvested from reefs or rocks allowed to cure under aquaculture conditions.

In response to a stakeholder request, the Mediterranean clone of C taxifolia was added to the Noxious Species List in 1999 by the US Department of Agriculture, Animal and Plant Health Inspection Service (USDA-APHIS), making interstate transport and importation illegal. Only the Mediterranean clone was included in this initial request. The term "Mediterranean clone" has been replaced by the more neutral "aquarium strain" by many scientists, and this term will be used here.

In 2001, California imposed stricter guidelines than the Federal Government in response to the two southern 
Californian invasions by the aquarium strain of $\mathrm{C}$ taxifolia; it became illegal to sell or possess $\mathrm{C}$ taxifolia or eight other species, some of which are easily confused with $\mathrm{C}$ taxifolia (C mexicana, C sertulariodes, C ashmeadii, C floridana, $\mathrm{C}$ cupressoides), and others that are considered invasive ( $\mathrm{C}$ racemosa, $\mathrm{C}$ scalpelliformis, $\mathrm{C}$ verticillata). The city of San Diego took this a step further and made it illegal to possess any species of Caulerpa. There has been local success in eradicating Caulerpa in southern California, but at a cost of over $\$ 5$ million (R Woodfield pers comm). Now a more concerted approach is necessary at the national level. The Aquatic Nuisance Species (ANS) Task Force released a National Management Plan for the genus Caulerpa in the fall of 2005, focused on supporting Caulerpa research and outreach, and the USDA-APHIS is currently considering whether to enhance regulation of this genus. Although both the ANS Task Force and USDA-APHIS acknowledge the potential importance of e-commerce as a mode of dispersal for these species, until now the importance of this vector has not been directly measured.

\section{Methods}

Between April 2003 and April 2005, using our central Florida address, we determined the diversity and availability of Caulerpa species via e-commerce and local retail outlets. The study involved 22 volunteers and over 200 internet search hours; we therefore consider our findings to be representative of the online availability of the genus. Volunteers chose their search dates and each time a volunteer began a search, he/she had 48 hours to find all the sources of Caulerpa available via online retail and eBay auctions, using their own choice of keywords. Keywords ranged from the obvious (eg Caulerpa, macroalgae) to less obvious terms, such as refugia, sea grapes, or marine cactus. Online purchases were made once from each dealer with any species of Caulerpa in stock, and from all unique eBay auctions that we won between March 11 and November 16, 2004 and between February 1 and March 18, 2005. We purchased Caulerpa from 51\% of the online retailers we identified (Caulerpa was frequently out of stock) and $44 \%$ of the auctions. In addition, we obtained Caulerpa spp from 25 of 47 (53\%) saltwater aquarium retail shops in central Florida (all Yellow Page-listed shops in the Tampa, Orlando, and Daytona Beach areas). We compared our data to those of Zaleski and Murray (in press), who conducted a similar survey of 50 southern California retailers between November 2000 and August 2001.

To determine the likelihood of purchasing live rock with Caulerpa growing on it, we purchased rocks from ten online retailers, ten eBay auctions, and ten local retailers during the same periods as described above. On the internet, "live rock" was the only keyword we used and we purchased it from the first ten retailers and eBay auctions we encountered that would sell us quantities of $10 \mathrm{~kg}$ or less.
Many distributors only wanted to supply $100 \mathrm{~kg}$ or more, shipped directly from the country of origin. All of the purchased live rock was maintained in separate, recirculating aquaria for 1 month.

\section{Results and discussion}

From 90 internet sites ( 30 online commercial retailers and 60 eBay auctions), Caulerpa spp were shipped to central Florida from shipping addresses in Great Britain and 25 US states, $52 \%$ of which were landlocked (Figures 1 and 2). Figures 1 and 2 document extensive interstate transport of this genus, especially via eBay. We separated our purchases into online retail versus eBay auctions for two reasons. First, internet retailers should be aware of federal regulations pertaining to the organisms they sell as part of their livelihood, while this may or may not be the case with eBay vendors, many of whom are home hobbyists. Information about restrictions on shipping Caulerpa to California was found on only two of the 30 retail websites from which we purchased material. eBay states that sellers are responsible for knowing all federal and state regulations for all live plants, animals, or animal products they sell and that vendors stand to have their accounts suspended and forfeit all eBay fees on the cancelled listings for breaking federal regulations. Of the 60 eBay auctions we won, only three vendors included information showing that they were aware of the restrictions on interstate transport of Caulerpa. In addition, one eBay vendor of $\mathrm{C}$ prolifera proudly, and correctly, stated that this species was permitted in, and could be shipped to, California. We never saw the aquarium strain of $\mathrm{C}$ taxifolia specifically listed on eBay, but "feather Caulerpa" was frequently seen for sale. Twelve of the 30 internet retailers were located in Florida and collected macroalgae locally, on demand. We also bought from two out-of-state retailers that supply live

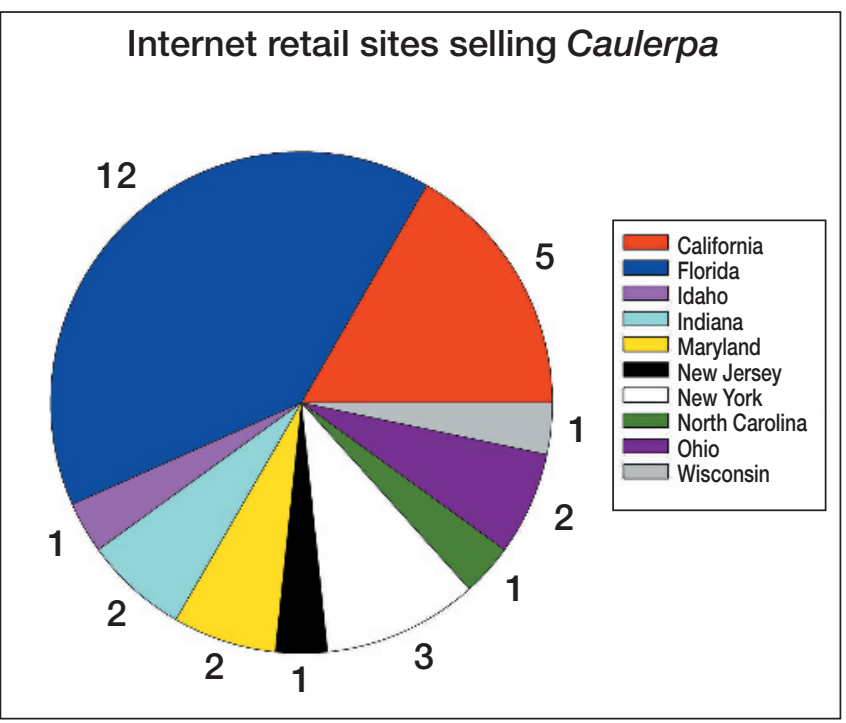

Figure 1. States with Caulerpa available for purchase from commercial internet retailers. Numbers associated with pie-charts indicate the number of retailers. 
materials to educational institutions that contracted with south Florida harvesters to supply Caulerpa as needed. Thus, $47 \%$ of our internet retail purchases never crossed state lines. Caulerpa spp were purchased from seven eBay auctions listing Florida as their address (12\%). This suggests much greater interstate dispersal of Caulerpa from eBay auctions than from internet retailers. It is also important to note that all of our purchases were delivered via the US postal service or one of many private shipping services; USDA-APHIS has no direct regulatory inspection authority over these entities.

Caulerpa costs varied greatly among sellers, with the least expensive being local retailers. The average cost for a handful of any species of the genus Caulerpa locally was $\$ 4.00$. Not included in this average is the free Caulerpa that we received from $43 \%$ of the local retailers. We always purchased the smallest amount available online. Units of purchase also varied greatly among dealers, ranging from 2-3 individuals to enough to fill a quart-size plastic bag $(22 \times 17 \mathrm{~cm})$ to "enough for a class of 35 students". The average cost for any single species of Caulerpa from internet retailers was $\$ 43.08$, and $\$ 18.09$ from eBay. In both cases, this price included packing and shipping charges, which ranged from $\$ 10$ to over $\$ 35$ per shipment.

From all purchased material, 13 different Caulerpa species were identified by us at the University of Groningen, using DNA sequencing (Figure 3). Details of all sequences and relationships for all collections, along with those of Zaleski and Murray (in press), will soon be submitted to GenBank and for publication (Stam et al. unpublished). Four species were available from all sources, whereas $\mathrm{C}$ cupressoides was only available via the internet (Figure 3). Of the 12 species shipped to central Florida, two species, Caulerpa serrulata and C taxifolia, have not been reported in Florida's coastal waters (Littler and Littler 2000; C Glardon pers comm).

Specimens of $\mathrm{C}$ taxifolia were purchased only once, from a southern California internet retailer (November 2004) and were listed online as "green feather Caulerpa". It proved to be the non-invasive type, based on DNA sequence analysis (Stam et al. unpublished). The one finding of $\mathrm{C}$ taxifolia suggests that this species is not being widely distributed in the US via e-commerce, hopefully as a result of awareness campaigns and USDA-APHIS regulations. The potential success of this early (preCalifornia invasion) USDA decision to restrict the aquarium strain of $\mathrm{C}$ taxifolia indicates that a genus-wide ban could be very effective in preventing future invasions and associated, extremely costly eradication efforts.

\section{Internet auction sites selling Caulerpa}

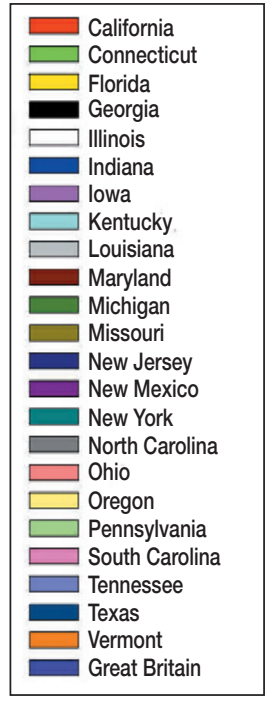
$4 \quad 1$
7 2

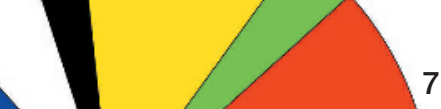

7
1
1

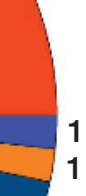

.
2

Figure 2. States/countries with Caulerpa available for purchase from eBay auctions.

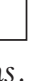




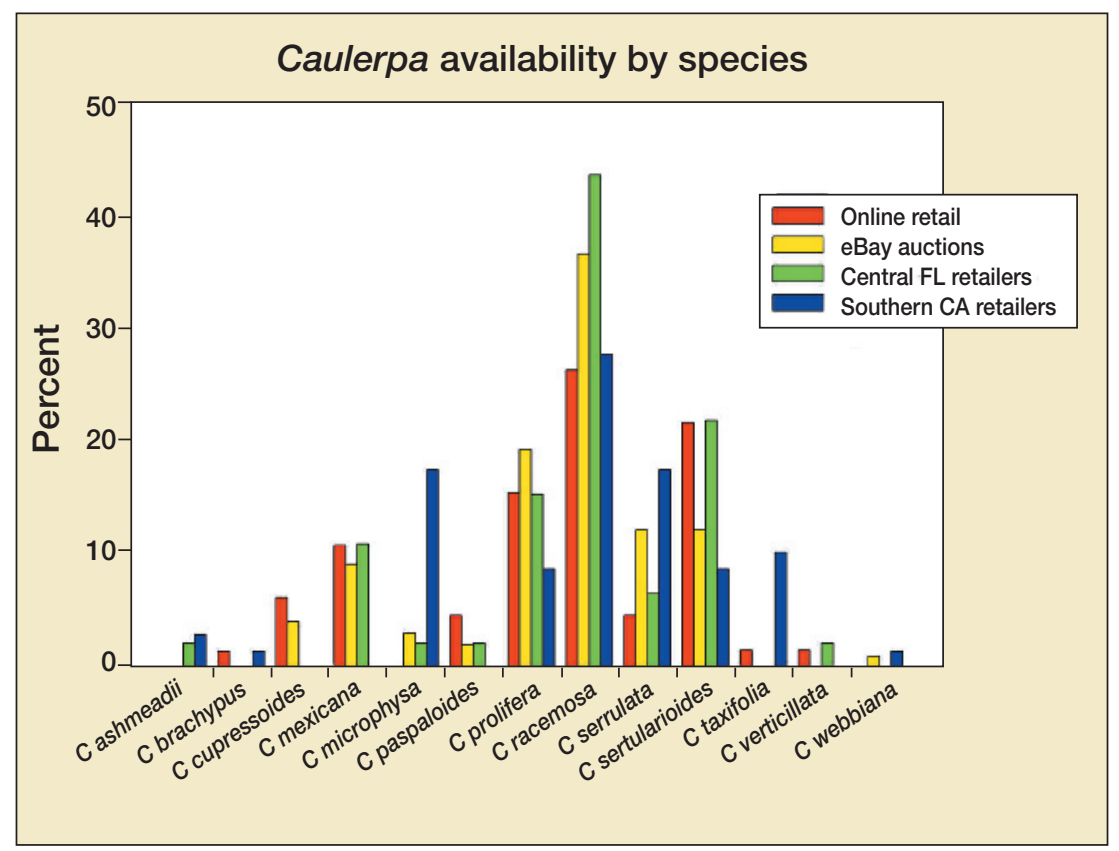

Figure 3. Percent availability of Caulerpa species from eBay auctions and online, Central Florida, and Southern California retail sources.

"Chaetomorpha Caulerpa" (actually Chaetomorpha). This high level of unreliability and variability makes both morphological identification by customs agents and internet tracking of Caulerpa difficult.

Finally, we discovered that Caulerpa, especially species of Caulerpa with feathery blades, was frequently pictured in entire aquarium set-ups for sale on internet auction sites. Items had to be collected in person, so we were able to acquire $\mathrm{C}$ racemosa and $\mathrm{C}$ mexicana by this means from only one auction initiated in Clermont, Florida. In total, ten states were represented in 13 auctions for complete, 30-120-gallon tank set-ups.

\section{Improving the future}

Internet availability of the genus Caulerpa, as well as numerous other algal species and invertebrates, represents a serious threat to Florida's coastlines in terms of non-native introductions from hobbyists. The $\$ 5$ million spent on Caulerpa eradication in California would be equivalent to 142857 purchases of loose Caulerpa at an average of $\$ 35$ per purchase. If $1 \%$ of these hobbyists dumped Caulerpa into nearby waters and $1 \%$ of these releases became established, then at least $\$ 70$ million (14 eradications $\mathrm{x} \$ 5$ million/response) will be required to achieve eradication. Pressuring eBay to eliminate all auctions of Caulerpa and enhanced federal regulation of Caulerpa would be considerably more cost-effective.

Commercial retail of invasive species is not limited to marine macroalgae or live rock. For example, Semmens et al. (2004) found 16 species of non-native, marine fishes in Florida waters; their data suggest aquarium dumping as the source for all these species. Only limited information was available online and in local retail shops to alert con- sumers to the dangers of "aquarium dumping". Locally, only two of 47 retailers had signs asking patrons not to dump unwanted organisms. On the internet, we found only six distributors (five retailers, one eBay auction) who warned against aquarium dumping. This limited amount of warning on improper disposal of unwanted marine organisms indicates that more and better outreach is needed. A new website, www.habitattitude.net, was recently created for just this reason. This national initiative has been developed by the ANS Task Force and the aquarium, pet, nursery, and landscape industries to raise consumer awareness about invasive species and alternatives to release of unwanted organisms into the wild. A number of other partners are also involved, including US and state-level Fish and Wildlife Services and the National Sea Grant College Program. By engaging and receiving support from the industries that distribute non-native flora and fauna for the first time, this outreach program has a much greater chance of success than previous federal and state-level efforts that operated on a more confrontational level. To date, only a limited number of retail outlets and suppliers have shown interest, but expectations are high that this campaign will help reduce the number of releases of invasive species in terrestrial, fresh, and marine systems.

\section{Acknowledgements}

We thank P Sacks, C Glardon, M Black, and all the searchers. For funding, we thank the National and Florida Sea Grant College Programs, Pinellas County Environmental Fund, Tampa Bay Estuary Program, Florida Department of Agriculture, University of Groningen, and the University of Central Florida. Suggestions by $\mathrm{P}$ Windle substantially improved this manuscript.

\section{References}

Belsher T and Meinesz A. 1995. Deep water dispersal of the tropical alga Caulerpa taxifolia introduced into the Mediterranean. Aquat Bot 51: 163-69.

Davis A, Roberts D, and Cummins S. 1997. Rapid invasion of a sponge-dominated deep-reef by Caulerpa scalpelliformis (Chlorophyta) in Botany Bay. Aust J Ecol 22: 146-50.

de Villèle X and Verlaque M. 1995. Changes and degradation in a Posidonia oceanica bed invaded by the introduced tropical alga Caulerpa taxifolia in the north western Mediterranean. Bot Mar 38: 79-87.

Jacoby C, Lapointe B, and Creswell L. 2004. Are native and nonindigenous seaweeds overgrowing Florida's east coast reefs? Gainesville, FL: Florida Sea Grant College Program SGEF-156.

Jousson O, Pawlowksi J, Zaninetti L, et al. 1998. Molecular evidence for the aquarium origin of the green alga Caulerpa taxifo- 
lia introduced to the Mediterranean Sea. Mar Ecol Prog Ser 172: $275-80$.

Jousson O, Pawlowski J, Zaninetti L, et al. 2000. Invasive alga reaches California. Nature 408: 157-58.

Littler D and Littler M. 2000. Caribbean reef plants. Washington, DC: OffShore Graphics, Inc.

Meinesz A. 1999. Killer algae. Chicago, IL: University of Chicago Press.

Meinesz A, Belsher T, Thibault T, et al. 2001. The introduced green alga Caulerpa taxifolia continues to spread in the Mediterranean. Biol Invas 3: 201-10.

Meusnier I, Valero M, Destombe C, et al. 2002. Polymerase chain reaction-single strand conformation polymorphism analyses of nuclear and chloroplast DNA provide evidence for recombination, multiple introductions and nascent speciation in the Caulerpa taxifolia complex. Mol Ecol 11: 2317-25.

Millar A. 2004. New records of marine benthic algae from New South Wales, eastern Australia. Phycol Res 52: 117-28.

Padilla D and Williams S. 2004. Beyond ballast water: aquarium and ornamental trades as sources of invasive species in aquatic ecosystems. Front Ecol Environ 2: 131-38.

Schaffelke B, Murphy N, and Uthicke S. 2002. Using genetic techniques to investigate the sources of the invasive alga Caulerpa taxifolia in three new locations in Australia. Mar Pollut Bull 44: 204-10.

Semmens B, Buhle E, Salomon A, and Pattengill-Semmens C. 2004. A hotspot of non-native marine fishes: evidence for the aquarium trade as an invasion pathway. Mar Ecol Prog Ser 266: 239-44.

Smith C and Walters L. 1999. Fragmentation as a strategy for
Caulerpa species: fates of fragments and implications for management of an invasive weed. PSZN I: Mar Ecol 20: 307-19.

Verlaque M, Afonso-Carrillo J, Candelaria Gil-Rodríguez M, et al. 2004. Blitzkrieg in a marine invasion: Caulerpa racemosa var. cylindracea (Bryopsidales, Chlorophyta) reaches the Canary Islands (north-east Atlantic). Biol Invas 6: 269-81.

Verlaque M, Durand C, Huisman J, et al. 2003. On the identity and origin of the Mediterranean invasive Caulerpa racemosa (Caulerpales, Chlorophyta). Eur J Phycol 38: 325-39.

Whitfield P, Gardner T, Vives S, et al. 2002. Biological invasions of the Indo-Pacific lionfish (Pterois volitans) along the Atlantic coast of North America. Mar Ecol Prog Ser 235: 289-97.

Wiedenmann J, Baumstark A, Pillen TL, et al. 2001. DNA fingerprints of Caulerpa taxifolia provide evidence for the introduction of an aquarium strain into the Mediterranean Sea and its close relationship to an Australian population. Mar Biol 138: 229-34.

Williams E and Grosholz E. 2002a. International Caulerpa taxifolia Conference Proceedings. California Sea Grant College Program, University of California, La Jolla, Pub No T-047.

Williams S and Grosholz E. 2002b. Preliminary reports from the Caulerpa taxifolia invasion in southern California. Mar Ecol Prog Ser 233: 307-10.

Williams S and Schroeder S. 2004. Eradication of the invasive seaweed Caulerpa taxifolia by chlorine bleach. Mar Ecol Prog Ser 272: 69-76.

Zaleski S and Murray S. Taxonomic diversity, geographic distribution, and commercial availability of aquarium-traded species of Caulerpa (Chlorophyta, Caulerpaceae) in southern California, USA. Mar Ecol Prog Ser. In press.

\section{TAKE THIS JOURNAL TO YOUR LIBRARIAN, PLEASE}

\section{Did you enjoy this issue of Frontiers?}

\section{If your library had a subscription, colleagues and students could enjoy it too.}

Please consider recommending Frontiers in Ecology and Environment to your library.

Clip or copy the form below.

\section{Library Recommendation Form}

To Acquisition Librarian, Serials

From

Dept

Signature Date

I recommend the library subscribe to: Frontiers in Ecology and the Environment (ISSN 1540-9295)

To request a free sample issue of Frontiers in Ecology and the Environment, call (301) 588-4691 or email Sika Dunyoh

at sika@esa.org. Order Frontiers by contacting ESA Headquarters at (202) 833-8773, online at www.esa.org, or through your subscription agent. 